\title{
The relation between dietary restriction or clenbuterol (a selective $\beta 2$ agonist) treatment on muscle growth and calpain proteinase $(E C$ 3 4.22.17) and calpastatin activities in lambs
}

\author{
BY JANET A. HIGGINS, YVONNE V. LASSLETT, R. G. BARDSLEY \\ AND P. J. BUTTER Y* \\ Department of Applied Biochemistry and Food Science, University of Nottingham School \\ of Agriculture, Sutton Bonington, Loughborough, Leics. LE12 5RD
}

(Received 14 October 1987-Accepted 20 July 1988)

\begin{abstract}
1. Lamb growth trials were designed to modify growth and protein content of muscle by diet and also by $\beta$-agonist treatment, and to correlate any changes to the activities of calpain proteinases $(E C 3.4 .22 .17)$ and their inhibitor calpastatin.

2. Wether lambs in a control group were fed on a barley-based diet designed to give a growth rate of $350 \mathrm{~g} / \mathrm{d}$; a second group was fed on the same diet but the intake was restricted to give an expected gain of $44 \mathrm{~g} / \mathrm{d}$; a third group was fed on the same diet as the first group but the diet included $2 \mathrm{mg}$ clenbuterol $/ \mathrm{kg}$. At the end of a 6-week trial, longissimus dorsi wet weights were $635(n 6), 377(n 4)$ and $788 \mathrm{~g}(n 6)$ (standard error of difference 53.0) in the three groups respectively.

3. Minced L. dorsi was extracted in low-salt buffers and analysed by a fast protein liquid-chromatographic system for calpain I (low calcium-requiring), calpain II (high $\mathrm{Ca}^{2+}$-requiring) and calpastatin activities. No significant changes in the three activities were associated with reduced muscle weight in the restricted-intake group. The inclusion of clenbuterol in the diet, however, led to highly significant increases $(P<0.001)$ in calpain II and calpastatin to approximately double the control values.

4. The results did not support a direct relation between these activities and muscle growth, except when protein accretion was stimulated by a $\beta$-agonist, suggesting a role for this enzyme system in the mechanism by which these agents exert their effect.
\end{abstract}

Increased efficiency of muscle growth and modification of the lean and fat content by dietary manipulation remain outstanding goals of the livestock industry. It is generally held that the balance between protein synthesis and breakdown in muscle must be altered for these goals to be achieved.

Muscle growth responds in a curvilinear fashion to increasing dietary intake. Protein synthesis and protein degradation increase with this increased growth rate (Waterlow et al. 1978). Muscle growth can also be stimulated by steroid hormone treatment. Testosterone given to female rats increased the rate of protein synthesis and, surprisingly, increased rate of breakdown, although not to the same degree (Martinez et al. 1984). In contrast, the group of compounds known as $\beta$-agonists is believed to increase protein deposition by suppressing degradation (Reeds et al. 1986; Bohorov et al. 1987). This mode of action on muscle is similar to that seen with the anabolic steroid trenbolone acetate (see Vernon \& Buttery, 1978; Sinnett-Smith et al. 1983). The rate of protein breakdown must ultimately be dependent on the activities of muscle proteolytic enzymes, and the possible contributions of lysosomal enzymes or the calcium-dependent neutral proteinases $(E C$ 3.4.22.17; CANPs or calpains), or both, have been much debated (Millward, 1985). Since calpain has the ability to degrade myofibrillar proteins, especially at the $\mathrm{Z}$ line (Dayton et al. 1975), a plausible model in which calpain initiates the limited proteolysis of the contractile proteins which are then taken into the lysosomes has been discussed (Gerard \& Schneider, 1980; Kay, 1983; Pemrick \& Grebenau, 1984). However, while increased calpain 
Table 1. Composition of experimental diet $(\mathrm{g} / \mathrm{kg}$ fresh weight)

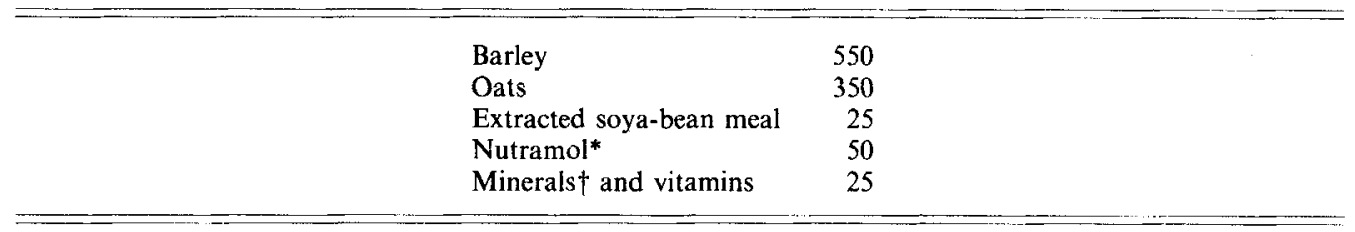

* A molassed peat product (Rumenco, Burton-on-Trent).

$\dagger$ Sheep minerals (Frank Wright, Ashbourne).

activity has been associated with increased proteolysis in atrophying or dystrophic muscle (Kar \& Pearson, 1976; Dayton et al. 1979), muscle calpain and calpastatin activity in chicks growing normally, albeit at different rates, in response to dietary protein levels did not vary (Ballard et al. 1988). Chicken calpain in vitro, however, requires a relatively high $\mathrm{Ca}^{2+}$ concentration for activity, in excess of expected physiological levels. Mammalian skeletal muscle contains in addition a low $\mathrm{Ca}^{2+}$-requiring form (calpain I or $\mu$-CANP), presumed to be active at the micromolar $\mathrm{Ca}^{2+}$ concentration expected in tissues, and therefore more likely to participate in breakdown as a part of normal turnover and growth.

In the present study, activities of calpains I and II ( $\mu$-CANP and m-CANP respectively) and calpastatin have been measured in lambs with dietary allowances designed to produce large differences in muscle growth. Second, the effect of clenbuterol, a $\beta$-agonist, on sheep muscle growth and the activity of the calpain-calpastatin system has been studied. These compounds have been shown to increase protein deposition and lean tissue and reduce fat content by stimulating lipolysis (Baker et al. 1984; Ricks et al. 1984; Bohorov et al. 1987).

\section{EXPERIMENT A L}

Animals and diets

The experiment was carried out with sixteen wether lambs (Suffolk $\times$ Clun Forest) over a period of 6 weeks. The lambs were blocked according to body-weight and randomly divided into three groups. One (the control group) was fed on the diet described in Table 1 ; the food offered was adjusted with reference to the body-weight so as to give a predicted gain of $350 \mathrm{~g} / \mathrm{d}$ (Agricultural Research Council, 1980). Routinely all food offered was consumed between feeds. The second group was given enough diet for a predicted gain of $44 \mathrm{~g} / \mathrm{d}$ (restricted-intake group). A third group was fed identically to that of group 1 except the diet contained $2 \mathrm{mg}$ clenbuterol $/ \mathrm{kg}$ diet. Daily allowances were given in two equal amounts at 09.30 and 16.30 hours. Lambs were weighed weekly. After 6 weeks animals were slaughtered and longissimus dorsi (left side) was removed immediately and frozen in liquid nitrogen before storage at $-40^{\circ}$ for subsequent enzyme analysis. L. dorsi (right side) was dissected out for wet-weight measurement and protein determination. The carcasses were cut vertically to expose 12 th and 13 th ribs, and L. dorsi muscle area could be measured.

\section{Chromatographic separation and quantification of calpains I and II and calpastatin}

Extraction. The direct measurement of calpain activities in crude homogenates is precluded by the presence of the inhibitor calpastatin. Chromatographic separation of the three components normally requires at least two steps using ion-exchange and hydrophobic columns (Inomata et al. 1983; Kawashima et al. 1984). Recently fast protein liquidchromatographic (FPLC) systems have become available and a one-step fractionation of 


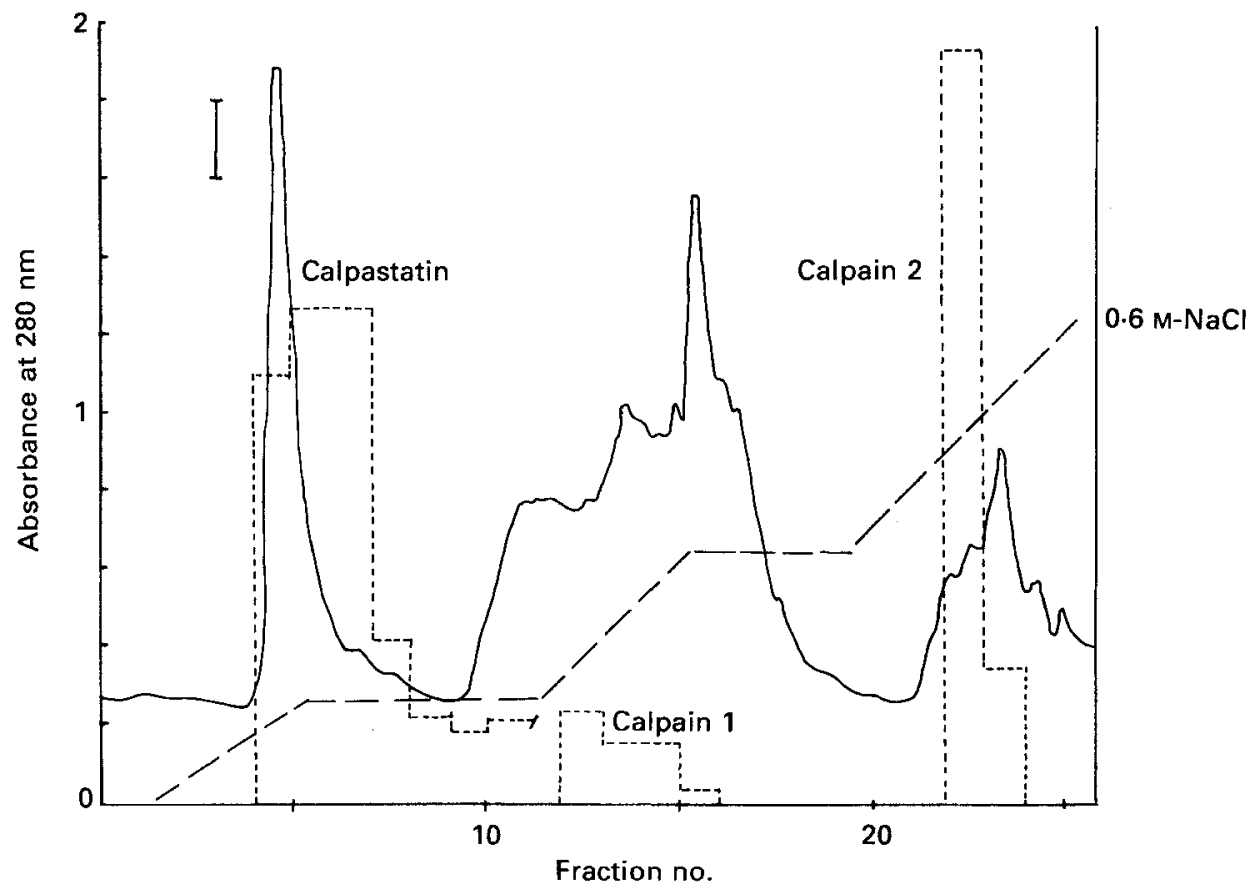

Fig. 1. Analysis of sheep muscle extract by fast protein liquid-chromatography. Filtered extract $(20 \mathrm{ml})$ in buffer A (see below) was loaded on to an $8 \mathrm{ml}$ mono Q column (Pharmacia) equilibrated with the same buffer. The proteins were eluted (collecting $5 \mathrm{ml}$ fractions) with a stepped gradient $(-\longrightarrow$ ) of total volume $120 \mathrm{ml}$ increasing from 0 to $0.6 \mathrm{M}$-sodium chloride in the same buffer, and monitoring absorbance at $280 \mathrm{~nm}$ of the eluent (-). Approximate enzyme and inhibitor activities are shown; vertical bar $=0.2$ activity units. Active fractions were pooled as appropriate, re-chromatographed in the case of calpain I, and activities measured accurately as described (p. 648).

the three components based on ion-exchange (Mono Q; Pharmacia, Uppsala, Sweden) has been developed. A one-step purification based on hydrophobic chromatography has also been described (Karlsson et al. 1985).

The extraction of enzymes and inhibitors was based on the procedure of Inomata $e t$ al. (1983). All steps were carried out at $0-4^{\circ}$ where possible. Thawed muscle was trimmed of external fat and connective tissue and finely chopped. Muscle (15 g) was homogenized (Polytron tissue homogenizer; Kinematica, Switzerland) with 3 vol. ice-cold buffer containing $20 \mathrm{~mm}$-Tris hydrochloride, $5 \mathrm{~mm}$-EDTA and $10 \mathrm{~mm}$-2-mercaptoethanol, $\mathrm{pH} 7.5$ (buffer A). The homogenate was centrifuged at $30000 \mathrm{~g}$ for $20 \mathrm{~min}$ and the supernatant fraction was filtered through two layers of nylon monofilament mesh followed by a $0.45 \mu \mathrm{m}$ filter and finally a $0.22 \mu \mathrm{m}$ filter (Millipore Corporation, Harrow, Middlesex).

Fractionation. Filtered extract $(20 \mathrm{ml})$ was loaded on to an $8 \mathrm{ml}$ Mono $\mathrm{Q}$ column (Pharmacia, Uppsala, Sweden) previously equilibrated with buffer A, using a loading rate of $4 \mathrm{ml} / \mathrm{min}$, at room temperature in accordance with the manufacturers' recommendations. The column formed part of a complete FPLC system supplied by Pharmacia. Elution was achieved using a stepped gradient from 0 to $0.6 \mathrm{M}$-sodium chloride, total volume $120 \mathrm{ml}$ (Fig. 1) programmed for maximum resolution of calpastatin and calpain I. Since tailing of calpastatin into the calpain I was found in some sheep extracts, the calpain I region (Fig. 1) in all samples was subjected, after dialysis to a lower $\mathrm{NaCl}$ concentration, to a second pass through a $1 \mathrm{ml}$ Mono $\mathrm{Q}$ column which reduced inhibitor contamination 
to negligible proportions. After initial detection of activity, appropriate fractions were pooled and reassayed for quantification of total activity.

Assays. Calpain activity was assayed essentially as described by Ishiura et al. (1982) as the production of trichloroacetic-acid-soluble peptides from casein digestion. Free $\mathrm{Ca}^{2+}$ was varied between 0 and $7 \mathrm{~mm}$ to distinguish calpains I and II. One unit of enzyme activity was defined as that amount of enzyme which produced an increase in absorbance at 280 $\mathrm{nm}\left(10 \mathrm{~mm}\right.$ path length) of 1.0 at $30^{\circ}$ for $30 \mathrm{~min}$. Calpains I and II were taken to be the enzyme activities half-maximally activated at $0.1 \mathrm{~mm}$ and $2 \mathrm{~mm} \mathrm{Ca}{ }^{2+}$ respectively. Routinely, assay and inhibition studies were carried out at $7 \mathrm{~mm}-\mathrm{Ca}^{2+}$. Peak fractions detected under these conditions were pooled and the assay checked for linearity with diluted pool samples. The assay was linearly dependent on enzyme concentration at least up to $0 \cdot 2$ units.

Calpastatin or inhibitor activity was measured by introducing portions of sample to a casein assay containing routinely $0 \cdot 2$ units of calpain II obtained from sheep muscle and incubating at $30^{\circ}$ for 30 min essentially as described by Lepley et al. (1985). Calpain II was chosen in preference to calpain I because of its higher activity in muscle and the inhibitor is more effective against calpain II. The decrease in absorbance at $280 \mathrm{~nm}$ in such assays compared with appropriate controls could be related to percentage inhibition. A regression line was fitted to the values obtained with various dilutions of the pooled inhibitor and the amount of inhibitor giving $50 \%$ inhibition of the calpain present was measured. One unit of inhibitor was the amount which would be required to inhibit one unit of calpain II under the standard assay conditions.

Protein determination. Muscle protein content was determined after Kjeldahl digestion and an automatic phenol-hypochlorite reaction (Davidson et al. 1970). The protein concentration in muscle extracts was measured using an assay kit (BioRad Laboratories, Walford, Hertfordshire). The kit was based on the change in absorbance of coomassie blue binding to the protein in the test solution.

\section{Statistical analysis}

Analyses of variance including a covariance adjustment for a gradual and apparently linear loss of enzyme and inhibitor activity with storage time (up to $30 \%$ after 6 months) were performed using the Genstat statistical package (Rothamsted Experimental Station, St Albans, Herts.). Muscle samples from the three groups were analysed in a random order.

\section{RESULTS}

Growth trial

The results of the effect of dietary intake and clenbuterol treatment on body-weight and L. dorsi characteristics are shown in Table 2 . The restricted-intake group had a significantly lower average daily live-weight gain (ADLWG) $(P<0.001)$ and L. dorsi wet weight and cross-sectional area $(P<0.001)$ compared with the control groups. The protein content and the extractable protein of the $L$. dorsi in the restricted-intake group were not significantly different from controls. The addition of $2 \mathrm{mg}$ clenbuterol $/ \mathrm{kg}$ to the diet did not affect ADLWG compared with the control animals but clearly resulted in an increase in L. dorsi wet weight $(P<0.01)$ and cross-sectional area $(P<0.01)$. The protein content of the clenbuterol-treated muscle increased $(P<0 \cdot 05)$.

\section{Extraction and separation of calpains $I, I I$ and calpastatin}

From Table 2, the amount of soluble protein extracted in test group samples was found not to differ significantly from samples in the control group. From Fig. 1, it can be seen that 
Table 2. Effect of dietary restriction or clenbuterol treatment on weight gain and longissimus dorsi characteristics in wether lambs

\begin{tabular}{|c|c|c|c|c|c|c|}
\hline \multirow[b]{2}{*}{ Dietary treatment $\dagger \ldots$} & \multirow[b]{2}{*}{$\begin{array}{l}\text { Control } \\
\quad(6)\end{array}$} & \multirow[b]{2}{*}{$\begin{array}{l}\text { Restricted- } \\
\text { intake } \\
\text { (4) }\end{array}$} & \multirow[b]{2}{*}{$\begin{array}{l}\text { Clenbuterol } \\
\text { (6) }\end{array}$} & \multicolumn{2}{|c|}{ Comparison of treatments } & \multirow[b]{2}{*}{$\begin{array}{l}\text { SED } \\
\text { (df 12) }\end{array}$} \\
\hline & & & & $\begin{array}{l}\text { Control } v \text {. } \\
\text { restricted- } \\
\text { intake }\end{array}$ & $\begin{array}{l}\text { Control } v \text {. } \\
\text { clenbuterol }\end{array}$ & \\
\hline Initial body-wt (kg) & $26 \cdot 6$ & $25 \cdot 8$ & $27 \cdot 2$ & NS & NS & 1.6 \\
\hline Wt gain $(\mathrm{kg})$ & $14 \cdot 6$ & $2 \cdot 0$ & $14 \cdot 4$ & $* * *$ & NS & 1.8 \\
\hline ADLWG (kg) & 0.347 & 0.048 & $0 \cdot 360$ & $* * *$ & NS & 0.037 \\
\hline \multicolumn{7}{|l|}{ Longissimus dorsi: } \\
\hline Wet wt $(\mathrm{g})$ & 635 & 377 & 788 & $* * *$ & ** & $53 \cdot 0$ \\
\hline Cross-sectional & & & & & & \\
\hline area $\left(\mathrm{cm}^{2}\right)$ & $21 \cdot 6$ & $12 \cdot 8$ & $26 \cdot 4$ & $* * *$ & ** & 1.7 \\
\hline Protein content $(\mathrm{g} / \mathrm{kg})$ & 204 & 204 & 221 & NS & * & $6 \cdot 2$ \\
\hline $\begin{array}{l}\text { Extractable protein } \\
(\mathrm{g} / \mathrm{kg})\end{array}$ & 41 & 36 & 48 & NS & NS & $5 \cdot 3$ \\
\hline
\end{tabular}

ADLWG, average daily live-weight gain; SED, standard error of difference; NS, not significant. ${ }^{*} P<0.05,{ }^{* *} P<0.01,{ }^{* * *} P<0.001$.

$\dagger$ For details, see Table 1 and p. 646.

the order of elution on the FPLC fractionation was calpastatin $(0.13 \mathrm{M}-\mathrm{NaCl})$, calpain I $(0 \cdot 24 \mathrm{M}-\mathrm{NaCl})$ and calpain II $(0.45 \mathrm{M}-\mathrm{NaCl})$. The calpain forms were identified by $\mathrm{Ca}^{2+}$. dependence as described previously (p. 648). The elution characteristics were very reproducible and did not vary between test and control samples. Similarly the $\mathrm{Ca}^{2+}$ dependence was the same in test and control groups.

These observations suggest that the physical characteristics of the three proteins studied were the same in test and control groups. Calpain I and calpastatin are normally found to co-elute on conventional ion-exchange chromatography with calpain II eluting at a higher ionic strength (Szpacenko et al. 1980; Murachi et al. 1981).

Calpastatin and calpain activities are given in Table 3, expressed in terms of units $/ \mathrm{kg}$ muscle and units/g extractable protein. Calpain and calpastatin activities have been adjusted by co-variance analysis to compensate for slight losses of activity increasing with time of storage at $-40^{\circ}$ up to $30 \%$ over 6 months (see p. 648).

Considering the control and restricted-intake groups, no significant changes in calpastatin and calpain II activities were detected no matter how the results were expressed. A significant reduction in calpain I $(P<0.05)$ expressed on the basis of muscle weight for the restricted-intake group disappeared when calculated on an extractable-protein basis. These results confirm the previous work with chickens (Ballard et al. 1988) of a lack of correlation between growth rate modified by dietary manipulation and activities of the calpain-calpastatin system.

Comparing the control group with the clenbuterol-treated animals, there was a highly significant doubling of calpastatin activity in the clenbuterol-treated animals, either expressed in units $/ \mathrm{kg}$ muscle $(P<0.001)$ or units $/ \mathrm{g}$ extractable protein $(P<0.01)$. A similar result was obtained with calpain II activity approximately doubling in the clenbuterol-treated animals. The increase was highly significant $(P<0.001)$ no matter how the values were expressed. The small reduction seen in calpain I activity on clenbuterol treatment was only significant $(P<0.05)$ when the values were expressed as units $/ \mathrm{g}$ extractable protein. 
Table 3. Effect of dietary restriction or clenbuterol treatment on calpains I and II (EC 3.4.22.17) and calpastatin activity in sheep longissmus dorsi muscle

\begin{tabular}{|c|c|c|c|c|c|c|}
\hline \multirow[b]{2}{*}{ Dietary treatment $\uparrow \ldots$} & \multirow[b]{2}{*}{$\begin{array}{l}\text { Control } \\
\text { (6) }\end{array}$} & \multirow[b]{2}{*}{$\begin{array}{l}\text { Restricted- } \\
\text { intake } \\
(4)\end{array}$} & \multirow[b]{2}{*}{$\begin{array}{c}\text { Clenbuterol } \\
\text { (6) }\end{array}$} & \multicolumn{2}{|c|}{ Comparison of treatments } & \multirow[b]{2}{*}{$\begin{array}{l}\text { Pooled } \\
\text { SED } \\
\text { (df 12) }\end{array}$} \\
\hline & & & & $\begin{array}{l}\text { Control } y . \\
\text { restricted- } \\
\text { intake }\end{array}$ & $\begin{array}{l}\text { Control } v \\
\text { clenbuterol }\end{array}$ & \\
\hline \multicolumn{7}{|l|}{ Units/kg muscle $\ddagger$} \\
\hline Calpastatin & 2740 & 2430 & 5440 & NS & $* * *$ & 420 \\
\hline Calpain I & 570 & 430 & 490 & $*$ & NS & 60 \\
\hline Calpain II & 1250 & 1500 & 2880 & NS & $* * *$ & 250 \\
\hline \multicolumn{7}{|l|}{$\begin{array}{l}\text { Units/g extractable } \\
\text { protein }\end{array}$} \\
\hline Calpastatin & 68 & 69 & 115 & NS & $* *$ & 13 \\
\hline Calpain I & $13 \cdot 6$ & $11 \cdot 8$ & $10 \cdot 2$ & NS & $*$ & 1.6 \\
\hline Calpain II & 30 & 41 & $6 \mathrm{I}$ & NS & $* * *$ & 5 \\
\hline
\end{tabular}

The calpastatin: calpain I or calpastatin: calpain II ratios did not change significantly in control and restricted-intake groups. In the clenbuterol-treated group, the calpastatin: calpain I ratio increased to 12 compared with 5 in controls. The calpastatin:calpain II ratio showed a small decrease from $2 \cdot 3$ to $1 \cdot 9$.

\section{DISCUSSION}

The present study sought to relate growth rate and protein content of sheep skeletal muscle, modified by dietary restriction or $\beta$-agonist administration, to the activities of the calpain proteinases and their specific inhibitor calpastatin. Since $\beta$-agonist administration had been reported to decrease muscle protein degradation in treated animals, corresponding changes in calpain activity might implicate these enzymes in myofibrillar protein breakdown during turnover.

Both dietary restriction and clenbuterol treatment had the predicted effects on growth and muscle characteristics (Table 2) with increased protein content in $\beta$-agonist-stimulated animals as reported previously (Bohorov et al. 1987). Although not fully purified, the physical characteristics of the sheep enzymes and inhibitor as judged by chromatographic behaviour and $\mathrm{Ca}^{2+}$ requirement were broadly similar to those described for other mammalian species (e.g. Kawashima et al. 1984) and did not vary detectably in treated and untreated samples. In control animals, recoveries of calpastatin, calpain I and calpain II after the FPLC steps were 2740,570 and 1250 units $/ \mathrm{kg}$ respectively, compared with 4200 , 275 and 2250 units $/ \mathrm{kg}$ reported for rabbit skeletal muscle after ion-exchange chromatography (Tsuji \& Imahori, 1981; Inomata et al. 1983; Nakamura et al. 1984).

Comparing the restricted-intake group of animals with controls, dietary restriction did not lead to significant differences in activity of calpains I and II and calpastatin (Table 3). This result extended the observation of Ballard et al. (1988) that chicken-muscle growth, but not the activity of the calpastatin-calpain system, could be manipulated by dietary means, to include the activity of the low $\mathrm{Ca}^{2+}$ requiring calpain I ( $\mu$-CANP) found in 
addition in mammalian muscle. The absence of changes in both calpain I and II contents on dietary restriction would argue against a role for either form of the enzyme in normal turnover at different growth rates. It has, however, to be accepted that the differences in degradation rate between the two groups may not have been large enough to be associated with detectable changes in the enzyme system.

In contrast, the addition of clenbuterol to the diet can be seen to have had a striking influence on the recovered activities of calpain II and calpastatin (Table 3). Both these activities were approximately doubled by the clenbuterol treatment, whereas the calpain I activity was not significantly affected. The inhibitor: enzyme ratio accordingly also doubled for calpain I but was unchanged for calpain II and the changes remained significant even after correction for the increased protein concentration in extracts of treated samples (Table 2). These results were interesting in several respects, for example, that calpains I and II should respond differently to clenbuterol treatment and that calpastatin and calpain II activities both increase in the same proportion.

The physiological roles of calpain I which is active at approximately $10 \mu \mathrm{M}-\mathrm{Ca}^{2+}$ in vitro and calpain II which requires approximately $5 \mathrm{mM}^{-\mathrm{Ca}^{2+}}$ have not been clarified. Because of the high $\mathrm{Ca}^{2+}$ requirement in vitro, calpain II has been suggested to be a precursor of the enzyme calpain, activated by autolysis (Pontremoli et al. 1985). Calpastatin inhibits calpain I at physiological $\mathrm{Ca}^{2+}$ levels (Szpacenko et al. 1980) but less effectively than it inhibits calpain II at $1 \mathrm{~mm}-\mathrm{Ca}^{2+}$, at least in vitro (Murachi et al. 1981). Interestingly, calpastatin is ineffective against the derived or autolysed form of calpain II (Pontromeli et al. 1985) and furthermore the calpastatin inhibition may be decreased against membrane-bound calpain II (Gopapakrishna \& Barsky, 1986). Since in the present study calpastatin activity increases in parallel with calpain II in response to $\beta$-agonist stimulation, either coregulation of both genes or increased solubilization of both proteins could be plausible explanations. If calpain II is a precursor form of the enzyme calpain, activated at high $\mathrm{Ca}^{2+}$ concentration, calpastatin may represent a partial buffer against transient changes in $\mathrm{Ca}^{2+}$ levels which are known to be associated with phosphatidyl inositol-linked receptor stimulation, for example, in platelets (Nishizuka, 1984).

A decrease in protein degradation would be expected to be associated with a decrease in calpain activity. If the inhibitory action of calpastatin is taken into account, calpain I activity is decreased in the clenbuterol-treated animals, whereas calpain II activity remains unchanged. Therefore, if calpain I was partially responsible for protein degradation this decrease might be associated with the expected lower muscle protein degradation rates (see Reeds et al. 1986; Bohorov et al. 1987) in the clenbuterol-treated animals. Responses of individual muscles to $\beta$-agonist treatment vary (see Bohorov et al. 1987). It would be interesting to relate these responses to changes in the calpain system in these different muscle types.

Recent advances on the role of calpains suggest that it is also worth exploring other explanations for the differences observed. Calpains have been implicated in receptor function either directly or via protein kinase C (Pontremoli et al. 1987). Limited proteolysis of the oestrogen (Puca et al. 1977) progesterone (Vedeckis et al. 1980) and epidermal growth factor receptor (Gates \& King, 1983) by a membrane-associated calpain II has already been reported. It would therefore be worth exploring if calpains could be involved in $\beta$-receptor function, processing or down-regulation.

The possibility that the increased inhibitor activity may have the net result of reducing overall calpain activity and hence protein degradation still, however, needs to be considered as a possible mode of action of $\beta$-agonists in muscle. Should this turn out to be the case, alternative strategies for increasing lean deposition in animals are suggested. Whatever the underlying mechanism, the findings suggest that clenbuterol treatment does not merely 
stimulate muscle protein gain by the same mechanism as is seen with increased dietary intake.

The support of Monsanto Europe is gratefully acknowledged.

\section{REFERENCES}

Agricultural Research Council (1980). Nutrient Requirements of Ruminant Livestock. Slough: Commonwealth Agricultural Bureaux.

Baker, P. K., Dalrymple, R. H., Ingle, D. L. \& Ricks, C. A. (1984). Journal of Animal Science 59, 1256-1261.

Ballard, R., Bardsley, R. G. \& Buttery, P. J. (1988). British Journal of Nutrition 59, 141-147.

Bohorov, O., Buttery, P. J., Correia, J. H. R. D. \& Soar, J. B. (1987). British Journal of Nutrition 57, 99-107.

Davidson, J., Mathison, J. \& Bone, A. M. (1970). Analyst 95, 181-193.

Dayton, W. R., Goll, D. E., Stromer, M. H., Reville, W. J., Zeece, M. G. \& Robson, R. M. (1975). Cold Spring Harbor Conference on Cell Proliferation: Proteases and Biological Control pp. 551-577. [E. Reich, D. B. Rifkin and E. Shaw, editors]. Cold Spring Harbor; N.Y.: The Cold Spring Harbor Laboratory.

Dayton, W. R., Schoilmeyer, J. V., Chan, A. C. \& Allen, C. E. (1979). Biochimica et Biophysica Acta 584, $216-230$

Gates, R. E. \& King, L. E. (1983). Biochemical and Biophysical Research Communications 113, 255-261.

Gerard, K. W. \& Schneider, D. L. (1980). Biochemical and Biophysical Research Communications 94, 1353-1361.

Gopapakrishna, R. \& Barsky, S. H. (1986). Journal of Biological Chemistry 261, 13936-13942.

Inomata, M., Hayashi, M., Nakamura, M., Imahori, K. \& Kawashima, S. (1983). Journal of Biochemistry 93, 291-294.

Ishiura, S., Tsuji, S., Murofushi, S. \& Suzuki, K. (1982). Biochimica et Biophysica Acta 701, 216-223.

Kar, N. C. \& Pearson, C. M. (1976). Clinica Chimica Acta 73, 293- 297.

Karlsson, J., Gustavsson, S., Hall, C. \& Nilsson, E. (1985). Biochemical Journal 231, 201-204.

Kawashima, S., Nomoto, M., Hayashi, M., Inomata, M., Nakamura, M. \& Imahori, K. (1984). Journal of Biochemistry 95, 95-101.

Kay, J. (1983). Proteases: Potential Role in Health and Disease, pp. 519-531. [A. Heidland and W. H. Horl, . editors]. London; Plenum Press.

Lepley, R. A., Pampusch, M. \& Dayton, W. R. (1985). Biochimica et Biophysica Acta 828, 95-103.

Martinez, J. A., Buttery, P. J. \& Pearson, J. T. (1984). British Journal of Nutrition 52, 515-521.

Millward, D. J. (1985). Biochemical Society Transactions 13, 1023-1026.

Murachi, T., Tanaka, K., Hatanaka, M. \& Murakami, T. (1981). Advances in Enzyme Regulation 19, 407-424.

Nakamura, M., Inomata, M., Hayashi, M., Imahori, K. \& Kawashima, S. (1984). Journal of Biochemistry 96, 1399-1407.

Nishizuka, Y. (1984). Nature 308, 693-698.

Pemrick, S. M. \& Grebenau, R. C. (1984). Journal of Cell Biology 99, 2297-2308.

Pontremoli, S., Melloni, E. \& Horecker, B. L. (1985). Current Topics in Cellular Regulation 27, 293-304.

Pontremoli, S., Melloni, E., Michetti, M., Sparatore, B., Salamino, F., Sacco, O. \& Horecker, B. L. (1987). Proceedings of the National Academy of Sciences, USA 84, 398-401.

Puca, B. A., Nola, E., Sica, V. \& Bresciani, F. (1977). Journal of Biological Chemistry 252, 1358-1366.

Reeds, P. J., Hay, S. M., Dorwood, P. M. \& Palmer, R. M. (1986). British Journal of Nutrition 56, 249-258.

Ricks, C. A., Dalrymple, R. H., Baker, P. K. \& Ingle, D. L. (1984). Journal of Animal Science 59, 1247-1255.

Sinnett-Smith, P. A., Dumelow, N. W. \& Buttery, P. J. (1983). British Journal of Nutrition 50, 225-234.

Szpacenko, A., Kay, J., Goll, D. E. \& Otsuka, Y. (1980). Proceinases and their Inhibitors: Structure, Function and Applied Aspects, pp. 151 161. [V. Turk and L. J. Vitale, editors]. Oxford: Pergamon Press.

Tsuji, S. \& Imahori, K. (1981). Journal of Biochemistry 90, 233-240.

Vedeckis, W. V., Freeman, M. R., Schrader, W. T. \& O'Malley, B. (1980). Biochemistry 19, 335-343.

Vernon, B. G. \& Buttery, P. J. (1978). British Journal of Nutrition 40, 563-572.

Waterlow, J. C., Garlick, P. J. \& Millward, D. J. (1978). Protein Turnover in Mammalian Tissues and in the Whole Body. Amsterdam: Elsevier North Holland. 